\title{
OLIVEIRA, Ricardo Costa de (autor e organizador). Análise dos parlamentares paranaenses na entrada do século XXI. Curitiba:
} APUFPR-SSind, 2002. 356 p.

\author{
Natália Cristina Granato ${ }^{1}$
}

- Enviado em 20/01/2016

- Aprovado em 14/02/2016

O estudo do poder legislativo e seus atores políticos (vereadores, deputados estaduais, deputados federais e senadores) é de suma importância para a compreensão da política e do Estado e a relação entre os seus poderes. Nesse sentido, um importante método para esse estudo é a análise do perfil de cada parlamentar eleito em uma dada conjuntura histórica. É o que o livro "Análise dos Parlamentares Paranaenses na entrada do século XXI" visa oferecer. O autor e organizador do livro, Ricardo Costa de Oliveira, é professor da Universidade Federal do Paraná e coordenador do Núcleo de Estudos Paranaenses. Juntamente com seus pesquisadores, assistentes e colaboradores do curso de Ciências Sociais, reuniu informações sobre todos os vereadores, deputados estaduais, federais e senadores eleitos pelo estado do Paraná na virada do século XX para o XXI, pertencentes à legislatura de 1999 a 2002, ano da publicação do livro. Também há análises dos resultados das eleições de 2002, oferecendo aos leitores os nomes dos parlamentares reeleitos.

Para cada cargo parlamentar nas suas esferas federal, estadual e municipal, há um banco de dados que apresenta informações dos objetos de estudo já referidos. Para os cargos de senador e deputado federal, o livro reuniu dados obtidos pelo Tribunal Regional Eleitoral do Paraná (TREPR) e pelo Departamento Intersindical de Assessoria Parlamentar (DIAP), além do Centro de Documentação e Informação da Câmara dos Deputados. Informações como dados pessoais, partido, contato, profissão, formação acadêmica, perfil e trajetória política de cada parlamentar são

\footnotetext{
${ }^{1}$ Graduada em Ciências Sociais pela Universidade Federal do Paraná (Bacharelado e Licenciatura). Mestranda em Sociologia pela Universidade Federal do Paraná. Bolsista da CAPES. Endereço eletrônico: nataliagranato@hotmail.com 
apresentados aos leitores individualmente, juntamente com o número absoluto de votos nos municípios com maiores êxitos eleitorais, principais doadores de campanha, base eleitoral e posicionamento político frente aos temas e decisões que marcaram a conjuntura temporal analisada (entrada do século XXI) As discussões em esfera federal mais destacadas eram sobre a flexibilização da CLT, o fator previdenciário, o fim do RJU, a conciliação nas empresas, a privatização da previdência dos servidores públicos, a redução do prazo prescricional, a responsabilidade fiscal, o combate ao nepotismo, a isenção dos empregados das custas por arquivamento de ações e os critérios para avaliação dos servidores.

Para o cargo de deputado estadual, as informações sobre a legislatura de 1999 a 2002 foram obtidas através do Tribunal Regional Eleitoral, do Cerimonial da Assembleia Legislativa do Paraná, além das consultas às secretárias e aos chefes dos gabinetes dos deputados. Dados como os resultados eleitorais, municípios de maiores votações obtidos pelos deputados, dados pessoais, acadêmicos e profissionais, filiações partidárias e trajetória política dos parlamentares. Os projetos de lei apresentados pelos mesmos no decorrer de seus mandatos também são contemplados. O percentual de presenças dos deputados nas seções até 2001, depoimentos de alguns deputados sintetizando um balanço dos seus mandatos foram contemplados, bem como o posicionamento de cada parlamentar frente à votação do projeto de iniciativa popular que proibia a venda da COPEL foram abordadas pelo livro, na conjuntura de privatizações de empresas estatais e avanço do neoliberalismo no momento de escrita do livro e reunião dos dados.

Já para a esfera parlamentar do município de Curitiba, a obra reuniu dados obtidos através do Movimento pela Ética na Política, no período de 1997 a 2001. Trata-se de um grupo de pesquisadores que acompanhou as sessões plenárias da Câmara Municipal, averiguando os projetos de lei apresentados, o desempenho dos parlamentares com os critérios de frequência, pontualidade, participação, atenção, fiscalização do executivo e qualidade dos Projetos de Lei apresentados.

Em suma, a obra resenhada traz importantes contribuições para o estudo do poder legislativo, sugerindo que tal análise leve em consideração a esfera regional e suas especificidades. O estado em questão é o Paraná, e tal levantamento de dados pode ser praticado pelas demais unidades da federação, oferecendo possibilidades de estudos comparativos. Também é possível atualizar tais dados, comparando o momento parlamentar atual com o de treze anos atrás, visto que as condições de pesquisa e levantamento de dados evoluíram qualitativamente nesses anos. 